\title{
Glaciecola mesophila sp. nov., a novel marine agar-digesting bacterium
}

\author{
Lyudmila A. Romanenko, ${ }^{1}$ Natalia V. Zhukova, ${ }^{2}$ Manfred Rohde, ${ }^{3}$ \\ Anatoly M. Lysenko, ${ }^{4}$ Valery V. Mikhailov ${ }^{1}$ and Erko Stackebrandt ${ }^{5}$ \\ ${ }^{1}$ Pacific Institute of Bioorganic Chemistry, Far-Eastern Branch, Russian Academy of Sciences, \\ 690022 Vladivostok, Prospekt 100 Let Vladivostoku, 159, Russia \\ ${ }^{2}$ Institute of Marine Biology, Far-Eastern Branch, Russian Academy of Sciences, 690041 \\ Vladivostok, Russia \\ ${ }^{3} \mathrm{GBF}$ - Gesellschaft für Biotechnologische Forschung, D-38124 Braunschweig, Germany \\ ${ }^{4}$ Institute of Microbiology, Russian Academy of Sciences, 117811 Moscow, Russia \\ ${ }^{5}$ DSMZ - Deutsche Sammlung von Mikroorganismen und Zellkulturen, Mascheroder Weg $1 \mathrm{~b}$, \\ D-38124 Braunschweig, Germany
}

Correspondence

Erko Stackebrandt

Erko@dsmz.de

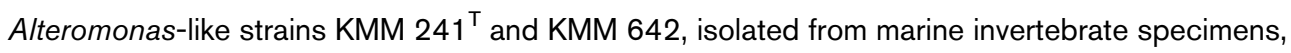
were investigated to clarify their taxonomic position. The novel isolates were aerobic, Gramnegative, motile, slightly halophilic and heterotrophic and hydrolysed polysaccharides. They did not hydrolyse urea, gelatin or casein and produced acid weakly from carbohydrates. The DNA G $+\mathrm{C}$ content ranged between 44.6 and 44.8 mol\%. DNA-DNA similarity between the two strains was $71 \%$. Comparison of the $16 \mathrm{~S}$ rRNA gene sequence of strain $\mathrm{KMM} 241^{\top}$ revealed $94 \cdot 5-94 \cdot 8 \%$ similarity to Glaciecola species. The novel strains shared several phenotypic and physiological properties with members of Glaciecola, but they differed in their lack of pigment production, their minimal and maximal growth temperatures and their ability to hydrolyse agar and carrageenan and in the utilization of organic compounds. On the basis of phenotypic and physiological characteristics as well as phylogenetic analysis, the isolates should be assigned to a novel species, Glaciecola mesophila sp. nov. The type strain is strain KMM $241^{\top}$ (=DSM $15026^{\top}$ ).
\end{abstract}

The genus Glaciecola, described to accommodate aerobic, psychrophilic, halophilic, pigmented bacteria, comprises two species, Glaciecola punicea and Glaciecola pallidula (Bowman et al., 1998). Members of Glaciecola have been isolated from sea-ice diatom assemblage samples collected from coastal areas of eastern Antarctica and seem to be restricted to sea-ice habitats (Bowman et al., 1998). The genus Glaciecola is phylogenetically closely related to Alteromonas macleodii within the $\gamma$-subclass of Proteobacteria. Alteromonas macleodii was originally described by Baumann et al. (1972) and the genus was later emended (Gauthier et al., 1995).

Strain KMM $241^{\mathrm{T}}$ was isolated from internal liquor of a specimen of the ascidian Halocynthia aurantium, collected from coastal sea water at a depth of $5 \mathrm{~m}$ in Troitsa Bay, Peter the Great Bay, Sea of Japan, Russia, in May 1990. Strain KMM 642 was isolated from tissue of the sponge Plocamia

Abbreviations: MA, Marine 2216 agar; MB, Marine 2216 broth; SWM, sea-water medium.

The GenBank/EMBL accession number for the $16 \mathrm{~S}$ rDNA sequence of strain $\mathrm{KMM} 241^{\top}$ is AJ488501. sp., at a depth of $350 \mathrm{~m}$ near the Komandorskie Islands, east of Kamchatka, in August 1991. A homogenate of the internal tissue was diluted aseptically in sterile sea water. Aliquots of internal liquor and diluted homogenate were spread on sea-water medium (SWM) agar plates $\left(1^{-1}: 5 \cdot 0 \mathrm{~g}\right.$ peptone, $2.5 \mathrm{~g}$ yeast extract, $1.0 \mathrm{~g}$ glucose, $0.2 \mathrm{~g} \mathrm{~K}_{2} \mathrm{HPO}_{4}$, $0 \cdot 05 \mathrm{~g} \mathrm{MgSO}_{4}, 500 \mathrm{ml}$ seawater, $500 \mathrm{ml}$ distilled water, $15 \cdot 0$ agar) and incubated for 7 days at $28^{\circ} \mathrm{C}$. Bacteria were stored at $-80^{\circ} \mathrm{C}$ in $30 \%(\mathrm{v} / \mathrm{v})$ glycerol. Strains KMM $241^{\mathrm{T}}$ and KMM 642 have been deposited in the Collection of Marine Micro-organisms (KMM), Pacific Institute of Bioorganic Chemistry, Vladivostok, Russia. The strains were routinely grown on Marine 2216 agar (MA, Difco), Marine broth (MB, Difco) and SWM at $7-30{ }^{\circ} \mathrm{C}$.

Gram-reaction, oxidase, catalase and production of amylase, caseinase, DNase, gelatinase and lipase (Tween 80) were tested according to the methods described by Baumann et al. (1984) and Smibert \& Krieg (1994), using MA or SWM as the basal medium. Hydrolysis of $\kappa$-carrageenan was determined as described by Yaphe \& Baxter (1955). Growth at different temperatures $\left(4-40{ }^{\circ} \mathrm{C}\right)$ and $\mathrm{pH}$ values $(5 \cdot 0-10 \cdot 0)$ was tested using $\mathrm{MA}$ and $\mathrm{MB}$; 
sodium ion requirement and tolerance of various $\mathrm{NaCl}$ concentrations $(0-12 \% \mathrm{NaCl})$ were assessed using SWM prepared from the artificial sea-water base supplemented with the appropriate amount of $\mathrm{NaCl}$. Motility was examined by the hanging-drop method. Leifson's medium was used for testing acid production from $1 \%(\mathrm{w} / \mathrm{v})$ carbohydrates (Leifson, 1963).

Additional biochemical tests using the API 20NE test kit (bioMérieux) and the Biolog GN MicroPlate method were performed as described by the manufacturers, except that strains were suspended in 3 or $2.5 \% \mathrm{NaCl}$. Cell morphology was examined by transmission electron microscopy from exponential-phase cells grown in MB. The cells were fixed with $1 \%(\mathrm{v} / \mathrm{v})$ glutaraldehyde and negatively stained with $4 \%(\mathrm{w} / \mathrm{v})$ aqueous uranyl acetate and carbonfilm. Samples were examined by a Zeiss TEM910 transmission electron microscope at an acceleration voltage of $80 \mathrm{kV}$ at calibrated magnifications. For determination of cellular fatty acid composition, strains KMM $241^{\mathrm{T}}$, KMM 642 and A. macleodii ATCC $27126^{\mathrm{T}}$ were grown on MA at 15 and $28^{\circ} \mathrm{C}$ for 2 days. Whole-cell fatty acids and phospholipids were examined according to the procedures described by Svetashev et al. (1995) and Ivanova et al. (2000). DNA base composition was determined as described by Marmur \& Doty (1962) and Owen et al. (1969). Optimal DNA-DNA relatedness was measured spectrophotometrically in $2 \times$ SSC with $10 \%$ DMSO at $68^{\circ} \mathrm{C}$, using the initial reassociation rate kinetic procedure (De Ley et al., 1970). Extraction of genomic DNA, PCRmediated amplification of the 16S rDNA and sequencing of PCR products were carried out as described by Rainey et al. (1996). Purified PCR products were sequenced directly using the Taq DyeDeoxy Terminator cycle sequencing kit (Applied Biosystems) according to the manufacturer's instructions. An Applied Biosystems 310 DNA Genetic Analyzer was used for electrophoresis of the sequence reaction products. The $16 \mathrm{~S}$ rDNA sequence of KMM $241^{\mathrm{T}}$ was compared with nucleotide sequences of the closest known relatives that were retrieved from the GenBank/EMBL databases. Phylogenetic dendrograms were reconstructed according to the method of De Soete (1983) and the neighbour-joining and maximum-likelihood methods (Felsenstein, 1993).

Cultural properties, cell morphology (Fig. 1), motility and the results of some basic physiological tests of strains KMM $241^{\mathrm{T}}$ and KMM 642 are described in the species description below. Cells were motile with a single unsheathed polar flagellum. Strains required sodium ions for growth and grew in $1-8 \% \mathrm{NaCl}$; they grew at $7-35^{\circ} \mathrm{C}$ but not at 4 or above $37^{\circ} \mathrm{C}$. Respective optima are indicated in the species description. Phenotypic properties of the novel strains and some reference organisms are compared in Table 1. Strains KMM $241^{\mathrm{T}}$ and KMM 642 differ from each other in acid production and utilization of some carbohydrates. Clear differences were observed between the novel isolates and the type strains of Glaciecola and Alteromonas
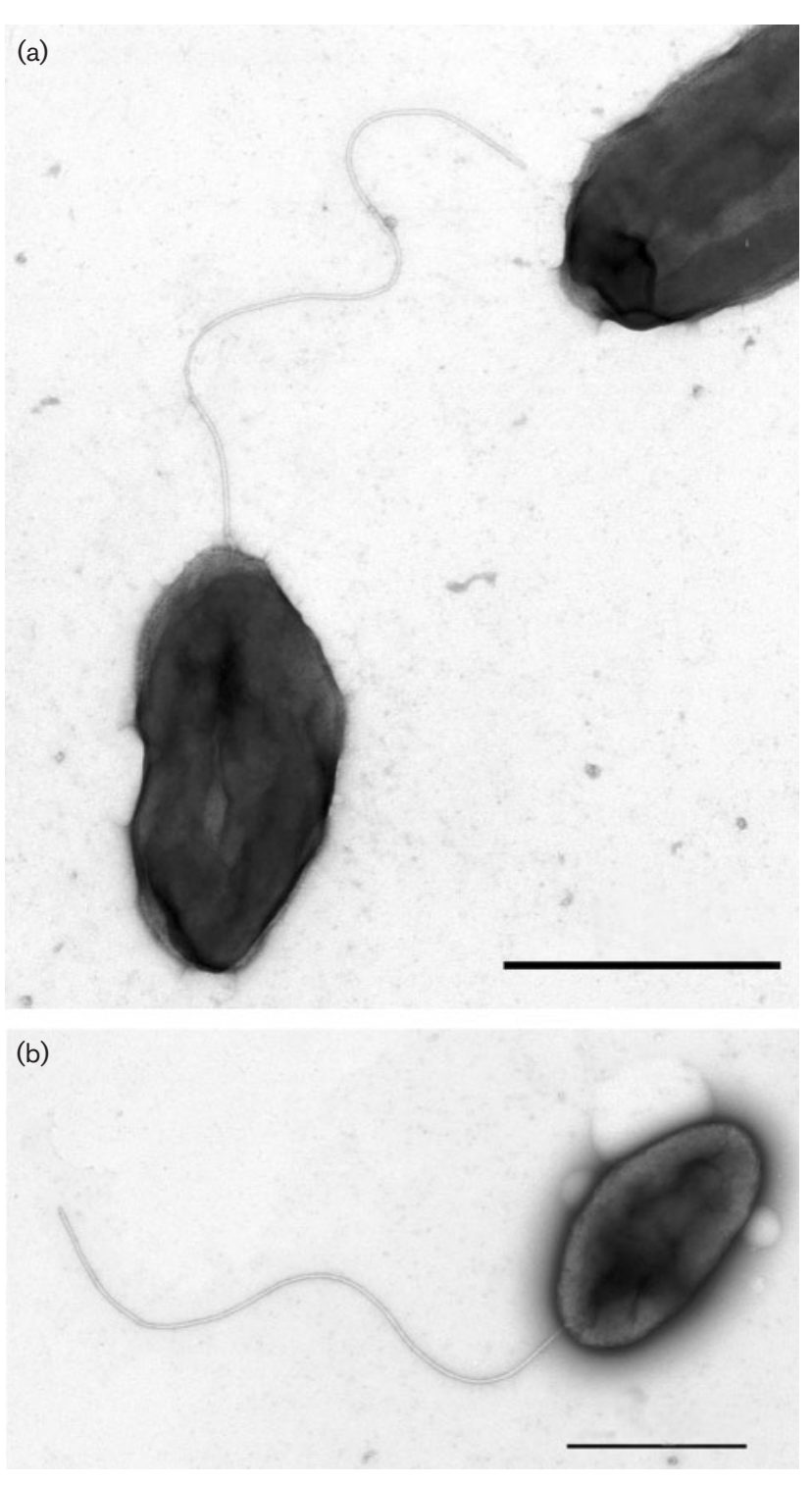

Fig. 1. Transmission electron micrographs of negatively stained

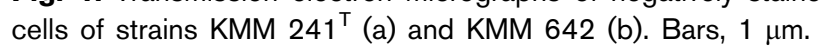

species in the patterns of utilization of carbohydrates and amino acids.

The strains possessed similar whole-cell fatty acid profiles and the dominant fatty acids, when grown at $28^{\circ} \mathrm{C}$, were $\mathrm{C}_{16: 0}(33 \cdot 0-40 \cdot 6 \%), \mathrm{C}_{16: 1 \omega 7 c}(35 \cdot 4-43 \cdot 0 \%)$ and $\mathrm{C}_{18: 1 \omega 7 c}$ $(5 \cdot 2-10 \cdot 1 \%)$ (Table 2). These profiles are similar to those of Alteromonas and Glaciecola strains, but the latter differ in the predominance of monounsaturated fatty acids over saturated fatty acids (Bowman et al., 1998). It should be noted that the fatty acid composition of strains KMM $241^{\mathrm{T}}$ and KMM 642 depended on the growth temperature. On decreasing the growth temperature from 28 to $15^{\circ} \mathrm{C}$, the proportions of $\mathrm{C}_{17: 1 \omega 8 c}$ and $\mathrm{C}_{18: 1 \omega 7 c}$ increased from $3 \cdot 2-2 \cdot 8$ to $6-8 \%$ and from 5 to $13 \%$ (for strain KMM 


\section{Table 1. Phenotypic characteristics of strains $\mathrm{KMM} 241^{\top}$ and $\mathrm{KMM} 642$, Glaciecola species and $A$. macleodii}

Strains/species: 1, strains KMM $241^{\mathrm{T}}$ and KMM 642; 2, G. punicea (data from Bowman et al., 1998); 3, G. pallidula (Bowman et al., 1998); 4, A. macleodii (Baumann et al., 1984, unless indicated otherwise). Reactions are scored as: +, positive; -, negative; $\mathrm{V}+$, variable between strains, type strain positive; $\mathrm{V}-$, variable between strains, type strain negative; $\mathrm{W}$, weak or delayed; ND, not determined. All strains were positive for the following tests: motility, sodium ion requirement for growth, oxidase, catalase, growth at $7-20{ }^{\circ} \mathrm{C}$ and growth in $1-6 \%$ $\mathrm{NaCl}$. All strains were negative for indole reaction, nitrate reduction, denitrification, arginine dihydrolase, chitin hydrolysis and utilization of L-arabinose, citrate, phenylacetate, adipate, L-phenylalanine, L-histidine, L-ornithine, L-threonine and putrescine.

\begin{tabular}{|c|c|c|c|c|}
\hline Property & $1^{\star}$ & 2 & 3 & 4 \\
\hline Filaments present & - & + & + & - \\
\hline \multicolumn{5}{|l|}{ Growth at: } \\
\hline 0 and $4{ }^{\circ} \mathrm{C}$ & - & + & + & - \\
\hline $25^{\circ} \mathrm{C}$ & + & + & - & + \\
\hline $37^{\circ} \mathrm{C}$ & - & - & - & + \\
\hline $40^{\circ} \mathrm{C}$ & - & - & - & $\mathrm{v}+$ \\
\hline Growth in $10 \% \mathrm{NaCl}$ & - & - & - & $+\dagger$ \\
\hline \multicolumn{5}{|l|}{ Hydrolysis of: } \\
\hline Urea & - & $\mathrm{W}$ & - & - \\
\hline Tween 80 & + & $\mathrm{v}-$ & + & + \\
\hline DNA & $\mathrm{W}$ & - & - & $+\dagger$ \\
\hline \multicolumn{5}{|l|}{ Acid from: } \\
\hline D-Glucose & $\mathrm{W}$ & $\mathrm{W}$ & $\mathrm{W}$ & $+\dagger$ \\
\hline Sucrose & $\mathrm{W},(-)$ & - & - & $+\dagger$ \\
\hline D-Galactose &,$-(\mathrm{w})$ & $\mathrm{w}$ & $\mathrm{w}$ & $-\dagger$ \\
\hline Maltose & - & - & $\mathrm{W}$ & $+\dagger$ \\
\hline Glycerol & - & $\mathrm{W}$ & $\mathrm{w}$ & $-\dagger$ \\
\hline \multicolumn{5}{|l|}{ Utilization of: } \\
\hline D-Glucose, sucrose, maltose & + & - & - & + \\
\hline D-Galactose, cellobiose, D-fructose, D-trehalose &,$+(-)$ & - & - & + \\
\hline Caprate & - & ND & ND & + \\
\hline L-Glutamate & - & - & + & ND \\
\hline$\alpha$-Glycerophosphate & $\mathrm{W},(-)$ & $\mathrm{v}+$ & + & $\mathrm{ND}$ \\
\hline Succinate, fumarate, L-malate, L-proline & - & + & - & - \\
\hline L-Serine &,$+(-)$ & - & - & $\mathrm{V}-$ \\
\hline L-Tyrosine & - & $\mathrm{v}+$ & - & + \\
\hline DNA G $+C$ content $(\mathrm{mol} \%)$ & $44 \cdot 8,(44 \cdot 6)$ & $44-46$ & 40 & $44-47$ \\
\hline
\end{tabular}

${ }^{*}$ Strains KMM $241^{\mathrm{T}}$ and KMM 642 were positive for acid production from D-fructose and D-mannose (weakly), ONPG test, $\alpha$-galactosidase, $\alpha$-cyclodextrin and glycyl L-glutamic acid utilization. Strain KMM $241^{\mathrm{T}}$ was positive for melibiose, $\beta$-hydroxybutyric acid and L-aspartic acid utilization; strain KMM 642 was positive for acid production from xylose (weakly) and L-alanyl glycine utilization. Both strains were negative for $\mathrm{H}_{2} \mathrm{~S}$ production and utilization of lactose, D-sorbitol, myo-inositol, adonitol, malonate, D-glucuronate, isobutyrate, valerate, isovalerate, caprylate, L-asparagine, hydroxy-L-proline and L-leucine. Where different reactions are shown, the reaction of strain KMM 642 is given in parentheses. $\dagger$ Data obtained in this study. 
Table 2. Fatty acid composition of strains $\mathrm{KMM} 241^{\top}$ and $\mathrm{KMM} 642$ and the type strains of Glaciecola species and $A$. macleodii

Values are percentages of total fatty acids. Data for Glaciecola species were taken from Bowman et al. (1998). The following fatty acids were detected in some or all strains at $<1 \%: 12: 1,13: 0,13: 1,13: 0 \mathrm{i}, 14: 0 \mathrm{i}, 15: 0 \mathrm{i}, 14: 1 \omega 5 c, 15: 0 \mathrm{a}, 15: 1 \omega 6 c, 17: 0 \mathrm{i}, 12: 0-3 \mathrm{OH}, 18: 0 \mathrm{i}$, $18: 1 \omega 11 c$ and $18: 1 \omega 9 c$. ND, Not detected.

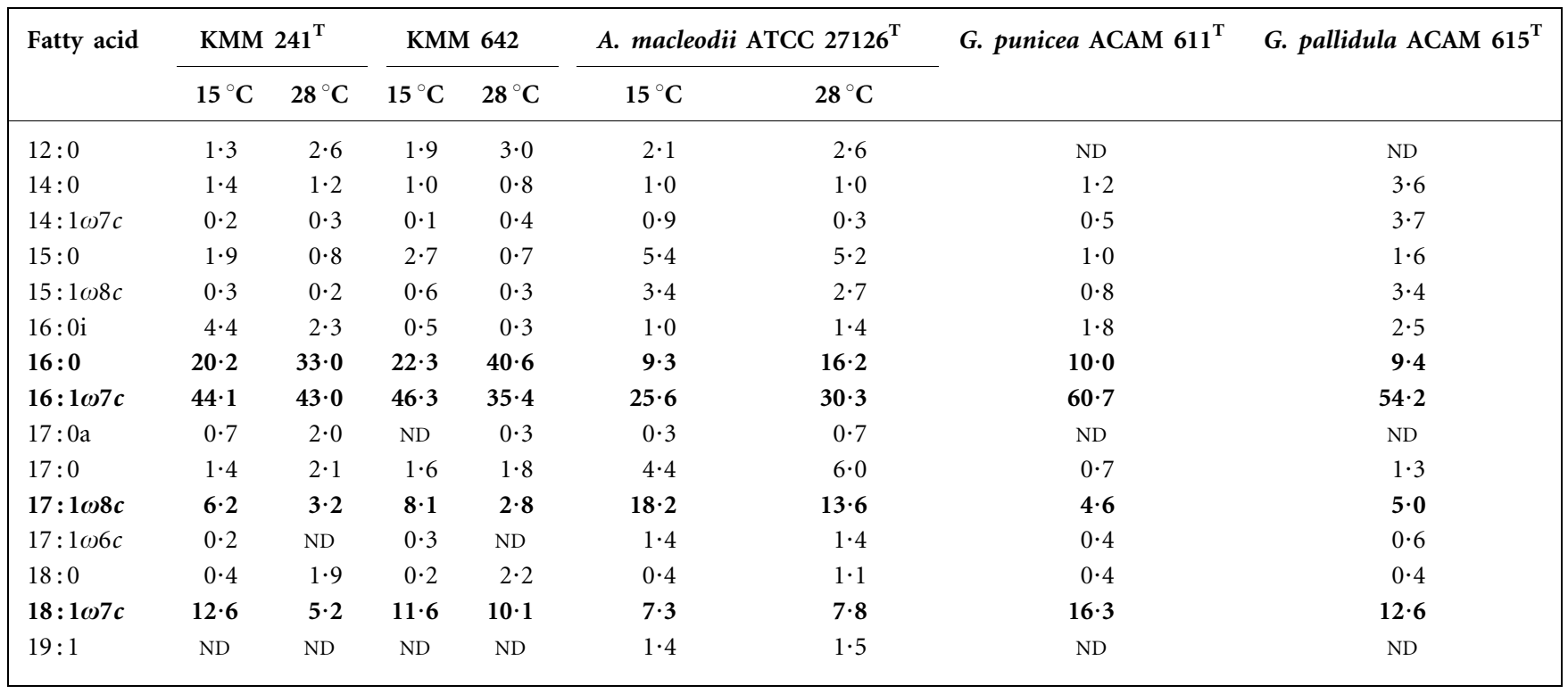

$241^{\mathrm{T}}$ ), respectively, while the relative amounts of $\mathrm{C}_{16: 0}$ and $\mathrm{C}_{16: 1 \omega 7 c}$ were constant or changed only slightly. A. macleodii did not show noticeable differences in the content of $\mathrm{C}_{17: 1 \omega 8 c}$ and $\mathrm{C}_{18: 1 \omega 7 c}$ when grown at different temperatures (Table 2).

The phospholipid compositions of strains KMM $241^{\mathrm{T}}$ and KMM 642 were similar and included phosphatidylethanolamine $(72 \cdot 1$ and $69 \cdot 4 \%$, respectively), phosphatidylglycerol $(23 \cdot 2$ and $23 \cdot 1 \%)$, diphosphatidylglycerol $(2 \cdot 5$ and $3 \cdot 4 \%)$ and bis-phosphatidic acid (2.2 and $4 \cdot 0 \%)$.

The DNA G + C contents of KMM 241 ${ }^{\mathrm{T}}$ and KMM 642 were respectively $44 \cdot 8$ and $44 \cdot 6 \mathrm{~mol} \%$. DNA-DNA hybridization experiments between the two strains showed DNA binding of $71 \%$.

$16 \mathrm{~S}$ rDNA sequence analysis revealed that the novel isolate KMM $241^{\mathrm{T}}$ is a phylogenetic neighbour of Glaciecola sp. strain HA02, described as decomposing Laminaria thallus (99.7\% similarity; accession number AB049729). Strain KMM $241^{\mathrm{T}}$ is phylogenetically closely related to G. punicea and G. pallidula (respectively 94.5 and $94 \cdot 8 \%$ sequence similarity) and somewhat less closely related to $A$. macleodii (93.4\% similarity). The $16 \mathrm{~S}$ rRNA gene sequence similarity between G. pallidula and G. punicea was $93 \cdot 3 \%$. Different algorithms consistently placed strain KMM $241^{\mathrm{T}}$ adjacent to the two Glaciecola type strains and the neighbour-joining dendrogram is shown in Fig. 2. The branching is supported by bootstrap values above $75 \%$.

The phenotypic (Table 1) and chemotaxonomic (Table 2) characteristics of the novel isolates are consistent with the description of Glaciecola species, including motility, requirement for sodium ions for growth, absence of growth in $10 \% \mathrm{NaCl}$, the presence of oxidase, catalase and $\alpha$-galactosidase activities, $\beta$-galactosidase production, the ability to hydrolyse aesculin, the lack of gelatinase, caseinase and urease activities, weak or delayed acid production from $\mathrm{D}$-glucose, $\mathrm{D}$-galactose and melibiose, $\mathrm{C}_{16: 0}, \mathrm{C}_{16: 1 \omega 7 c}$ and $\mathrm{C}_{18: 1 \omega 7 c}$ as major fatty acids and $\mathrm{G}+\mathrm{C}$ content of $44 \cdot 6-44 \cdot 8 \mathrm{~mol} \%$.

The novel bacteria can be distinguished from Glaciecola species by the following characteristics: the inability to produce pigments, to form filaments and to grow at $0-4{ }^{\circ} \mathrm{C}$ and the ability to degrade agar, carrageenan and DNA (weakly) and to utilize D-glucose, sucrose,

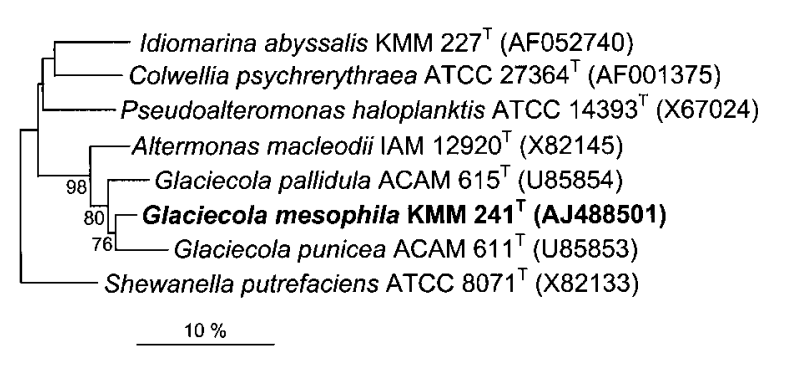

Fig. 2. Neighbour-joining analysis of $16 \mathrm{~S}$ rRNA gene sequences showing the position of strains $\mathrm{KMM} 241^{\top}$ among Glaciecola species. Percentages at branching points refer to bootstrap analyses (500 resamplings). Scale bar, 10 inferred nucleotide substitutions per 100 nucleotides. 
D-mannitol, glycyl L-glutamic acid, cellobiose, maltose, D-galactose, D-fructose, D-mannose, L-serine, D-trehalose and $\beta$-hydroxybutyric acid.

On the basis of their phenotypic, chemotaxonomic, genomic and phylogenetic characteristics, we conclude that strains KMM $241^{\mathrm{T}}$ and KMM 642 should be placed in the same species within the genus Glaciecola as Glaciecola mesophila sp. nov.

\section{Description of Glaciecola mesophila sp. nov.}

Glaciecola mesophila (me.so' phi.la. Gr. adj. mesos medium; Gr. adj. philos loving; N.L. fem. adj. mesophila mediumtemperature-loving, mesophilic).

Aerobic, Gram-negative, oxidase- and catalase-positive, non-pigmented, non-spore-forming, ovoid or curved rodshaped cells, $1 \cdot 2-1 \cdot 5 \mu \mathrm{m}$ long and $0 \cdot 6-0 \cdot 8 \mu \mathrm{m}$ in diameter, motile with single unsheathed polar flagella. Does not form filaments. On MA, forms smooth, convex, nonpigmented colonies, translucent or whitish with regular edges, $3-5 \mathrm{~mm}$ in diameter, depressed into the agar. Slightly halophilic. Requires sodium ions for growth (1-8\% NaCl), optimum between 2 and $5 \%$; no growth in $10 \% \mathrm{NaCl}$. Growth occurs between 7 and $35^{\circ} \mathrm{C}$, but not at $4-5$ or $40{ }^{\circ} \mathrm{C}$; optimum between 25 and $28^{\circ} \mathrm{C}$. The $\mathrm{pH}$ range is $5 \cdot 5-9 \cdot 5$, optimum at $\mathrm{pH} 8 \cdot 0-8 \cdot 5$. Chemoorganoheterotroph. Positive for lipase, amylase and $\beta$-galactosidase and $\alpha$-galactosidase, decomposition of agar and carrageenan. Produces acid weakly from carbohydrates. Other phenotypic and biochemical tests are listed in Table 1. Predominant fatty acids are $\mathrm{C}_{16: 0}, \mathrm{C}_{16: 1 \omega 7 c}$ and $\mathrm{C}_{18: 1 \omega 7 c}$. Phospholipids include phosphatidylethanolamine, phosphatidylglycerol, diphosphatidylglycerol and bis-phosphatidic acid. The G+C content of the DNA is $44 \cdot 6-44 \cdot 8 \mathrm{~mol} \%$ (thermal denaturation method).

The type strain, strain KMM $241^{\mathrm{T}}$ (=DSM $15026^{\mathrm{T}}$ ), was isolated from the ascidian Halocynthia aurantium in coastal sea water of the Sea of Japan. A reference strain, strain KMM 642, was isolated from a sponge Plocamia sp. at a depth of $350 \mathrm{~m}$ near the Komandorskie Islands.

\section{Acknowledgements}

We thank Ina Kramer and Jolantha Swiderski for excellent technical assistance in $16 \mathrm{~S}$ rDNA sequencing and data analysis. We are grateful to Dr Susanne Verbarg and Anja Frühling for providing API and Biolog tests. This study was supported by grant no. 02-04-49517 of the Russian Foundation for Basic Research, grant 95-01/03-19 from the Ministry for Industry and Science (MIS) of the Russian Federation (RF) and a grant from the Programme
'Biodiversity' of the MIS RF and Russian Academy of Sciences.

\section{References}

Baumann, L., Baumann, P., Mandel, M. \& Allen, R. D. (1972). Taxonomy of aerobic marine eubacteria. J Bacteriol 110, 402-429.

Baumann, P., Gauthier, M. J. \& Baumann, L. (1984). Genus Alteromonas Baumann, Baumann, Mandel and Allen 1972, $418^{\mathrm{AL}}$. In Bergey's Manual of Systematic Bacteriology, vol. 1, pp. 343-352. Edited by N. R. Krieg \& J. G. Holt. Baltimore: Williams \& Wilkins.

Bowman, J. P., McCammon, S. A., Brown, J. L. \& McMeekin, T. A. (1998). Glaciecola punicea gen. nov., sp. nov. and Glaciecola pallidula gen. nov., sp. nov.: psychrophilic bacteria from Antarctic sea-ice habitats. Int J Syst Bacteriol 48, 1213-1222.

De Ley, J., Cattoir, H. \& Reynaerts, A. (1970). The quantitative measurement of DNA hybridization from renaturation rates. Eur $J$ Biochem 12, 133-142.

De Soete, G. (1983). A least square algorithm for fitting additive trees to proximity data. Psychometrika 48, 621-626.

Felsenstein, J. (1993). PHYLIP (phylogenetic inference package) version 3.5.1. Distributed by the author. Department of Genetics, University of Washington, Seattle, USA.

Gauthier, G., Gauthier, M. \& Christen, R. (1995). Phylogenetic analysis of the genera Alteromonas, Shewanella, and Moritella using genes coding for small-subunit rRNA sequences and division of the genus Alteromonas into two genera, Alteromonas (emended) and Pseudoalteromonas gen. nov., and proposal of twelve new species combinations. Int J Syst Bacteriol 45, 755-761.

Ivanova, E. P., Zhukova, N. V., Svetashev, V. I., Gorshkova, N. M., Kurilenko, V. V., Frolova, G. M. \& Mikhailov, V. V. (2000). Evaluation of phospholipid and fatty acid compositions as chemotaxonomic markers of Alteromonas-like proteobacteria. Curr Microbiol 41, 341345.

Leifson, E. (1963). Determination of carbohydrate metabolism of marine bacteria. J Bacteriol 85, 1183-1184.

Marmur, J. \& Doty, P. (1962). Determination of the base composition of deoxyribonucleic acid from its thermal denaturation temperature. J Mol Biol 5, 109-118.

Owen, R. J., Hill, L. R. \& Lapage, S. P. (1969). Determination of DNA base compositions from melting profiles in dilute buffers. Biopolymers 7, 503-516.

Rainey, F. A., Ward-Rainey, N., Kroppenstedt, R. M. \& Stackebrandt, E. (1996). The genus Nocardiopsis represents a phylogenetically coherent taxon and distinct actinomycete lineage: proposal of Nocardiopsaceae fam. nov. Int J Syst Bacteriol 46, 1088-1092.

Smibert, R. M. \& Krieg, N. R. (1994). Phenotypic characterization. In Methods for General and Molecular Bacteriology, pp. 607-655. Edited by P. Gerhardt, R. G. E. Murray, W. A. Wood \& N. R. Krieg. Washington, DC: American Society for Microbiology.

Svetashev, V. I., Vysotskii, M. V., Ivanova, E. P. \& Mikhailov, V. V. (1995). Cellular fatty acids of Alteromonas species. Syst Appl Microbiol 18, 37-43.

Yaphe, W. \& Baxter, B. (1955). The enzymic hydrolysis of carrageenan. Appl Microbiol 3, 380-383. 